\title{
強電離・弱電離レーザプラズマチャンネルによる放電誘導
}

$\begin{array}{llll}\text { 正員島田 義則* } & \text { 正 員 内田 成明* } \\ \text { 正 員 河崎善一郎** } & \text { 正 員 山中 龍彦** } \\ \text { 正 員 高城 貫弘*** } & \text { 正 員 古岡 芳弘*** } \\ \text { 名誉員 山中千代衛* } & & \end{array}$

\section{Experiments of Discharge Guiding using Strongly and Weakly Ionized Plasma Channel produced by KrF Laser}

\author{
Yoshinori Shimada*, Member, Shigeaki Uchida ${ }^{*}$, Member, Zen-ichiro Kawasaki ${ }^{* *}$, Member, Tatsuhiko Yamanaka ${ }^{* *}$, Member \\ Yasuhiro Takagi $^{* * *}$, Member, Yoshihiro Furuoka ${ }^{* * *}$, Member, Chiyoe Yamanaka ${ }^{*}$, Honorary Member
}

We have studied the feasibility of a hybrid discharge method (to guide the discharge with strongly and weakly ionized plasma channels) of a long guiding laser plasma channel. Charged particle densities in a weakly ionized plasma channel were measured as a function of the laser intensity. Critical condition of the weakly ionized plasma to guide an electrical streamer was determined. The electrical resistibility of plasma channel to generate the self-propagating streamer is smaller than $3.5 \Omega \mathrm{m}$. The self-propagating streamer could heat the channel and leads to a main discharge.

キーワード : レーザ誘雷, 強電離プラズマ, 弱電離プラズマ, 放電誘導, エキシマレーザ

Keywords : laser-triggered lightning, strongly ionized plasma, weakly ionized plasma, discharge guiding, excimer laser

\section{1. はじめに}

冬季における日本海沿岸での超高圧送電線の雷事故は 2 回線事故になるケースが多く電力系統に及ぼす影響は大き い。このため電力業界にとっては，重要な課題の 1 つであ る。これを解決するための積極的な雷害対策の 1 つとして レーザ誘雷が提案研究されている(1) (4)。レーザ誘雷の概念 は，雷撃点となる高い誘雷塔を設置し，その先端に生ずる 高電界中にレーザでプラズマを生成し，上向きリーダを発 生させ，レーザプラズマに沿って上向きリーダを上空に進 展させる。十分に進展したリーダは自己進展して雷雲まで 到達し，誘雷塔に落雷させることにより雷電荷を中和させ て落雷による被害を低減することである。

\footnotetext{
* (財) レーザー技術総合研究所

干 550-0004 大阪市西区鞋本町 1-8-4

Institute for Laser Technology

1-8-4, Utsubo-honmachi, Nishi-ku, Osaka 550-0004

** 大阪大学

干 565-0871 吹田市山田丘 2-1

Osaka University

2-1, Yamada-oka, Suita 565-0871

関西電力 (株)

干 661-0974 尼崎市若王子 3-11-20

Kansai Electric Power Co., INC.

3-11-20, Nakoji, Amagasaki 661-0974
}

一般に, 雷は雷雲から地上に向かって進展するものであ るが，この方法はレーザプラズマによって強制的に上向き リーダを発生させること，次にそのリーダが自己進展でき る高さまでプラズマチャンネルによってガイドすることが 必要である。

当研究所は，実験室に於けるレーザ誘導放電に関する基 礎研究を基に日本海側の冬季雷を研究対象としてレーザ誘 雷の野外実験を行い, 強電離レーザプラズマを誘雷塔先端 に生成することによりリーダの発生に成功すると共に世界 で始めて自然雷の落雷塔への誘導に成功し, レーザ誘雷の

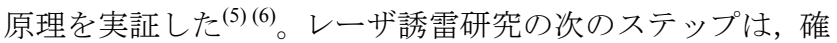
実にリーダをガイドし，主放電を生じさせることである。 このためには長距離に渡って放電をレーザプラズマチャン ネルでガイドすることが必要である。しかし， $\mathrm{CO}_{2}$ レーザを 用いて長距離にわたりレーザプラズマを生成するためには 大出力レーザ装置が必要となり実用上問題がある。このた め, 強電離プラズマチャンネル（主に赤外光レーザによっ て生成）にかわって, 弱電離プラズマチャンネル（紫外光 レーザによって生成）を組み合わせた方法が必要となる。

強電離・弱電離のプラズマの長, 短所を述べる。赤外光 レーザにより生成された強電離プラズマ（荷電粒子密度 $\mathrm{n}$ 
$\left.>10^{15} \mathrm{~cm}^{-3}\right)$ は, 単位長さに生成されるプラズマ密度が高く, 放電のトリガ効果に優れている, しかし, 単位長さ当たり に投入するエネルギーが大きい欠点がある。一方，紫外光 レーザを用いた弱電離プラズマ(荷電粒子密度 $\mathrm{n}<10^{15} \mathrm{~cm}^{-3}$ ) は, 誘雷塔先端から発生するコロナ放電による空間電荷密 度と同程度の密度であるために, 鉄塔先端のコロナシース を突き破りリーダを生成することは困難であるが，弱電離 プラズマの生成条件を最適化することにより, 強電離プラ ズマで発生したリーダを長尺に渡ってガイドすることが可 能である。紫外光と赤外光レーザを組み合わせた放電誘導 実験は多数の研究機関で行われており (7) (9), 強電離プラズ マ方式と比べ小さなエネルギーで放電ガイドが可能である ことなどが明らかとなっている。

著者らは強電離・弱電離プラズマおのおのの長所を生か すために，それらを直列につなげたハイブリッド方式を新 たに提案した。放電トリガ効果の高い強電離プラズマを雷 雲の電界下で高電界のかかる誘雷塔先端から上空に生成す ることでリーダを発生させる。そして発生したリーダを自 己進展可能な高さまで弱電離プラズマチャンネルでガイド してやることでリーダは雷雲まで進展することが可能とな る。強電離・弱電離プラズマを直列につなげ, 強電離プラ ズマを誘雷塔の先端に生成することによりリーダを生成し やすくしたことが新規性である。

この方式を使用するにあたり, 弱電離プラズマチャンネ ルの条件を明らかにする必要がある。即ち, 強電離プラズ マがリーダをトリガする条件は既に実験で求められている が弱電離プラズマがリーダ（或いはストリーマ）をガイド するための条件（抵抗率，電子密度等）は実験的に明らか となっていない。筆者らは, 実験室内においてリーダ（実 験室内ではストリーマ）をガイドするための弱電離プラズ マ条件を実験的に求めた。

\section{2. 紫外光レーザによって生成される荷電粒子密度}

レーザ強度とそれにより大気中に生成される弱電離プラ ズマ密度について調べた。初期電荷密度は平板電極を用い たチャージコレクト方式を用いて測定した。 $30 \mathrm{~mm}^{\phi}$ の平板 一平板電極に高電圧を印加しておき，ギャップ間にレーザ による弱電離プラズマを生成すると, 電界によって荷電粒 子は電極に引き寄せられる。この電荷をコンデンサ $(22 \mathrm{nF})$ に蓄積し, 積分することによってプラズマ内の電荷密度を 評価する。印加される $\mathrm{E}$ （電界 $\mathrm{V} / \mathrm{cm}$ ）/p（気圧 torr）に対 するコンデンサー両端の検出電圧変化は, $\mathrm{E} / \mathrm{p}$ が低い場合は 再結合や, 拡散による電荷の消滅が生じるために, 印加電 圧に比例して増加する。 $\mathrm{E} / \mathrm{p}$ が $5 \mathrm{~V} / \mathrm{cm}$ ・ torr を越えると電荷 の消滅と外部電界による 2 次電子の放出が釣り合った状態 となり検出電圧に飽和現象が現れ， $12 \mathrm{~V} / \mathrm{cm} ・$ torr を越える と 2 次電子の生成が活発となり検出電圧は急激に増加する。 初期電荷を算出するには検出電圧が飽和する值を用いるこ とにより, 初期に生成された弱電離プラズマの初期電荷が 測定できる(10)。実験では $9.1 \mathrm{~V} / \mathrm{cm} ・$ torr を用いた。レーザは
$\mathrm{KrF}$ （波長 $248 \mathrm{~nm}$, パルス幅は $30 \mathrm{~ns}$ ) と 4 倍高調波 $\mathrm{YAG}$ (波 長 $266 \mathrm{~nm}$ ，パルス幅は $3 \mathrm{ns）レーザの} 2$ 種類を用いた。ま た, 焦点距離 $2 \mathrm{~m}$ のレンズを用いてレーザ光を集光した。集 光点でのレーザ光のバーンパターンはレーザの出射口が 30 $\times 10 \mathrm{~mm}$ であるために $1.2 \times 3.5 \mathrm{~mm}$ である。 $2 \mathrm{~m}$ のレンズを 用いて集光した場合, $\mathrm{KrF}$ レーザの回折限界時のビームウエ ストは $31 \mu \mathrm{m}$ であることから, ビーム品質が悪く絞られて

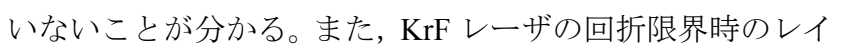
リー長は $31 \mathrm{~mm}$ であるが，ビーム品質が悪いために $30 \mathrm{~mm}^{\phi}$ の平板一平板電極内ではほぼ一定の断面積であった。以上の ことより, 断面積 $1 \times 3 \mathrm{~mm}$, 長さ $30 \mathrm{~mm}$ の領域の平均弱電 離プラズマ密度を評価した。

レーザのエネルギーを変化した場合の電荷粒子密度変化 を図 1 に示す。 (当研究所で測定)，○， $\square$ 印は $\mathrm{KrF} レ$

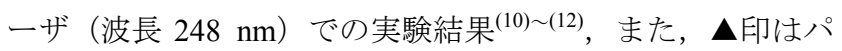
ルス幅 $3 \mathrm{~ns}$ の YAG レーザと非線形結晶（BBO 結晶）を用 いて $4 \omega$ 光（波長 $266 \mathrm{~nm}$ ）を照射した場合に得られたデー タである。図より, 集光強度を増加させると荷電粒子密度 は増加し, その傾きは 1.1 となった。粒子密度 $\mathrm{N}$ を多光子 吸収の式に当てはめると

$$
N \propto \tau \cdot(\sigma I)^{1.1}
$$

で表される。 N， $\sigma ， \mathrm{I} ， \tau$ はそれぞれ，生成荷電粒子密度， 荷電粒子生成断面積，レーザ強度，レーザパルス幅である。 上式より，多くの弱電離プラズマを生成させるためには, レーザ強度及びパルス幅を長くすることが必要である。ま た, 荷電粒子密度はレーザ強度の 1.1 乗に比例するので, 1.1 光子で 1 電離 $(248 \mathrm{~nm}$ の光子エネルギーは $5 \mathrm{eV}, 5.5 \mathrm{eV}$ で 1 電離）が生じていることを示す。大気を構成する主な元素 (窒素, 酸素, 等) で, イオン化ポテンシャルが $5.5 \mathrm{eV}$ 以 下の元素は見つからなかったが, 実験結果より, $5.5 \mathrm{eV}$ で電 離している。このため, イオン化されている粒子は大気中 に含まれる不純物であると思われる。電離気体を特定する

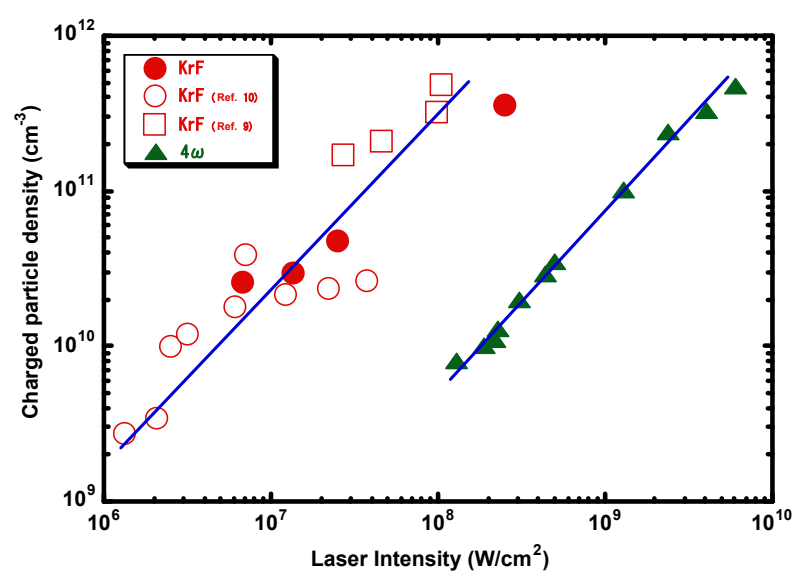

図 1 レーザ照射強度に対する生成された荷電粒子密度 Fig. 1. Charged particle density depends on laser intensity and wavelength of laser. 
ため, 大気中に含まれる様々な無機, 有機の気体について テストを行った ${ }^{(13)}$ 。しかし，大気の粒子密度より $8 \sim 10$ 枌 低い不純物を同定することは難しく同定には至っていな い。また, 窒素, 酸素の励起準位からの電離過程も考えら れる。

\section{3. 強電離・弱電離プラズマ中での放電進展過程}

実験は誘雷塔先端と雷雲を模した棒一平板電極を用いて 行った（図 2）。ギャップ間隔は $14.5 \mathrm{~cm}$ で，棒電極の直径 は $3 \mathrm{~cm}^{\phi}$ で, 先端は $3 \mathrm{~cm}^{\phi}$ の半球状である。平板電極は直径 $1.2 \mathrm{~m}$ のアルミ板を使用した。切れ目なく連続した強電離プ ラズマを棒電極の先端に生成するために，塩化ビニール製 の絶縁物を棒電極の側面に取り付けた。長さは，強電離プ ラズマの先端で高い電位傾度が得られるようにコロナ放電 領域を考慮して $3.5 \mathrm{~cm}$ とした。棒電極へは直流電圧 $-150 \mathrm{kV}$ を印加した。電圧印加 1 分後での定常コロナ電流は $300 \mu \mathrm{A}$ であった。このコロナ放電による空間電荷を考慮して，負 極性においても定常状態であれば適用可能な簡便電界計算 法(14) で求めた絶縁物先端での電界強度は 9.7〜 7.8 $\times 10^{5} \mathrm{~V} / \mathrm{m}$ である。

使用したレーザは $\mathrm{KrF}$ レーザで，これにより弱電離プラ ズマと強電離プラズマ生成の両方を同時に生成した。出力

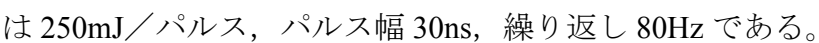
レーザ光は焦点距離 $\mathrm{f}=2.0 \mathrm{~m}$ のレンズで集光し，平板電極中 央に設けた導入穴を通して絶縁物を入射した。集光点は絶 縁物ターゲットと平板電極の中間地点とした。平板電極か ら棒電極までの空間に生成された弱電離プラズマ密度は集 光点までの位置により異なり，7.5〜 $11 \times 10^{10} \mathrm{~cm}^{-3}$, プラズマ 線密度は $2.4 〜 2.5 \times 10^{6} \mathrm{~cm}^{-1}$ で，長さは絶縁物先端からレー ザ導入穴までの $11 \mathrm{~cm}$ である。弱電離プラズマチャンネルを 生成した残りのレーザエネルギーは棒電極先端の絶縁物上 に照射され，強電離プラズマを生成する。

最大出力電圧 $\pm 100 \mathrm{kV}$ の直流電圧印加装置を 2 台使用し, 棒電極に負電圧を，平板電極に正電圧を同じ電圧だけ印加

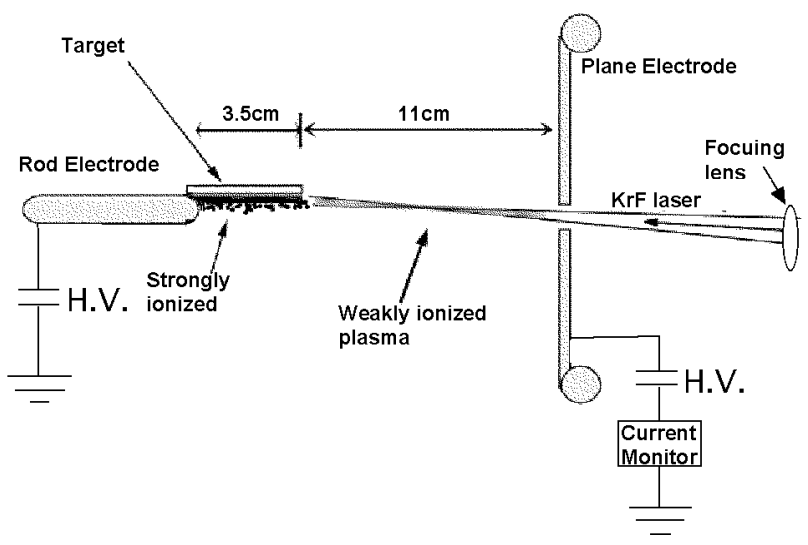

図 2 ハイブリッド放電実験配置

Fig. 2. Experimental setup for Hybrid plasma channels guided discharge.
した。レーザ照射は，棒電極先端に定常状態のコロナシー スが形成されるまでの時間, 約 60 秒後に行った。レーザを $80 \mathrm{~Hz}$ で照射した場合の $50 \%$ フラッシオーバー電圧は-150 $\mathrm{kV}$ であった。レーザプラズマによる放電誘導実験は印加電 圧- $150 \mathrm{kV}$ ，レーザ繰り返し周波数 $80 \mathrm{~Hz}$ で行った。

レーザを単一パルス照射した場合のストリーマの進展過 程をストリークカメラで観測した結果を図 3 に示す。印加 電圧は $0 \mathrm{kV}$ と $95 \mathrm{kV}$ の 2 種類で行った。縦軸が空間方向, 下部が棒電極側，上部が平板電極側である。横軸が時間で ある。印加電圧が $0 \mathrm{kV}$ の場合は弱電離プラズマ部分の発光 は見られないが, $95 \mathrm{kV}$ 印加時では棒電極から平板電極に向 けて負のストリーマが進展する様子が観られた。主放電に は至らなかった。

次に, $1 \Omega$ の抵抗を電流モニタとして挿入して測定した印 加電圧 $-150 \mathrm{kV}$ 時の, ギャップ間に流れる電流を図 4 に示す。 主放電には至っていない。電流はレーザのパルス幅よりも 短い $20 \mathrm{~ns}$ 程度で立ち上がり, その後減衰する。この電流波 形より求めた電荷量は約 $30 \mathrm{nC}$ である。 $30 \mathrm{nC}$ の電荷量は強 電離と弱電離プラズマが印加電界により電子増倍をおこし 流れた電流である。

次にレーザ照射を繰り返した場合について述べる。レー ザ誘導放電は放電路のプラズマ密度が低いため, 1 回のレー ザ照射では放電が起こらない。主放電に至るまでにはレー ザ照射の繰り返しが必要で，多くは数発目で主放電に至る

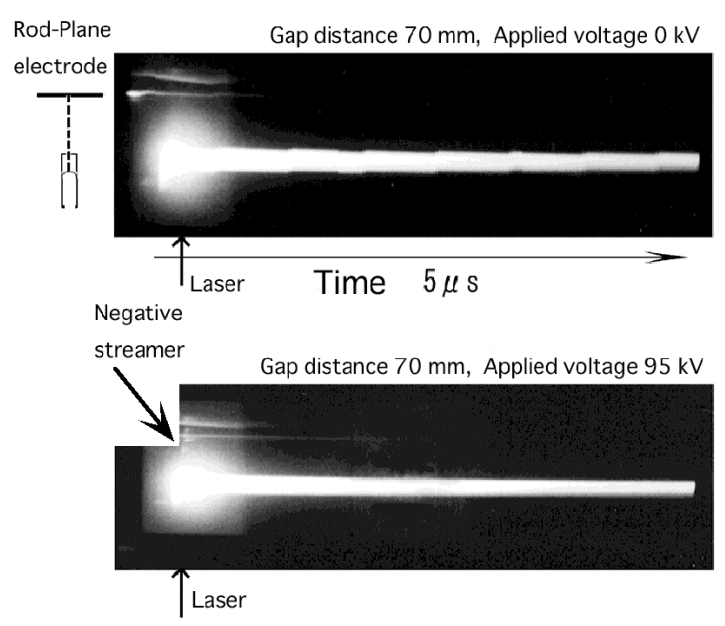

図 3 負極性ストリーマのストリーク写真

Fig. 3. Streak photograph of negative streaker though laser plasma channels.

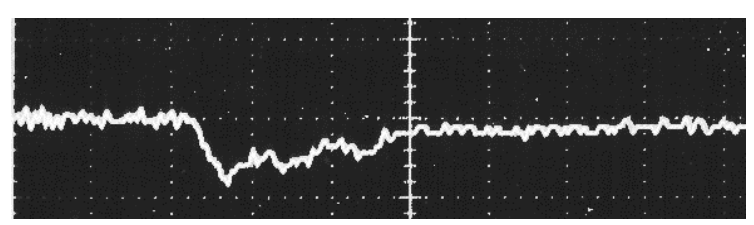

図 4 レーザを照射した場合に流れる電流波形

Fig. 4. Electric current waveform (500 mV/div, $100 \mathrm{~ns} /$ div $)$. 


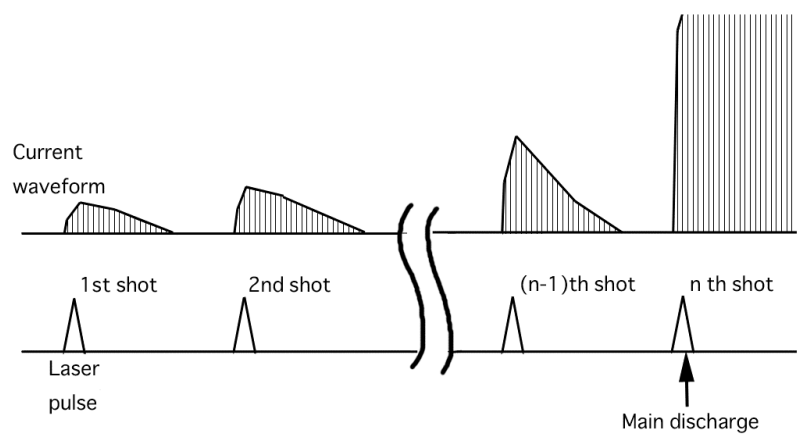

図 5 繰り返しによる電荷量の増加概念図

Fig. 5. Concept of the electric cahrge increaseing by the repetition of the laser.

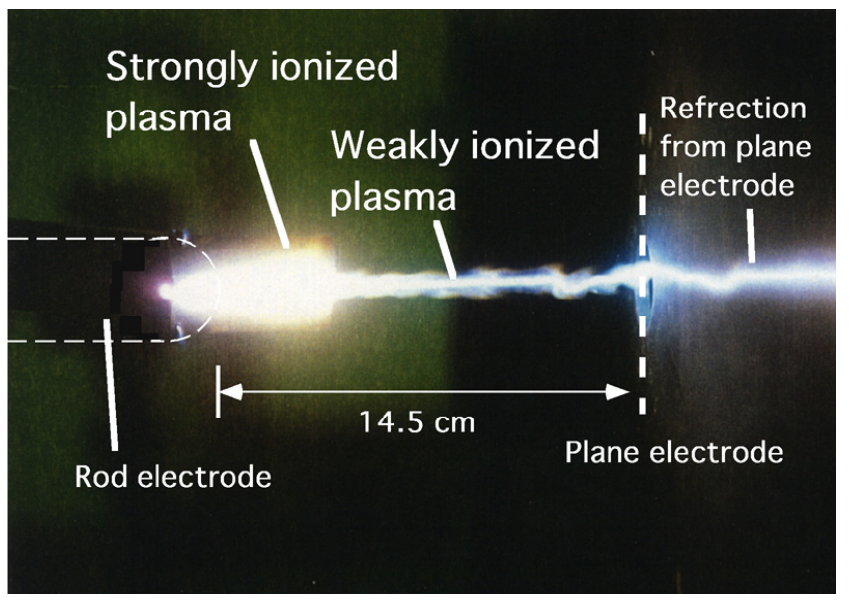

図 6 強電離・弱電離プラズマによる放電誘導 Fig. 6. Discharge photograph guided by the strongly and weakly ionized plasma channel.

（図 5)。レーザを数回繰り返し，放電が生じた様子を図 6 に示す。放電路は弱電離プラズマに沿って直線的に進展す る。

放電したときのレーザ照射回数を $\mathrm{N}_{\mathrm{f}}$, 注目しているレー ザパルスまでの回数を $\mathrm{N}_{\mathrm{ob}}$ として, 主放電到達割合 $\mathrm{N}_{\mathrm{ob}} / \mathrm{N}_{\mathrm{f}}$ を定義する。主放電時の主放電到達割合 $\mathrm{N}_{\mathrm{ob}} / \mathrm{N}_{\mathrm{f}}$ は 1 である。 $\mathrm{N}_{\mathrm{ob}} / \mathrm{N}_{\mathrm{f}}$ が増すことによって, プラズマチャンネルの発光量 が増加する様子を図 7 に示す。発光する場所は棒電極から 進展し平板電極に伸びる。また，レーザ照射回数が増える につれてチャンネル発光の強さが増す。

主放電まで至った場合のストリーク写真を図 8 (a)にま た，そのときの電流を図 8 (b)示す。(a)図より，最後のレー ザが照射されプラズマチャンネルに沿って負のストリーマ が進展する。次に自己進展する数本の正ストリーマが平板 電極から棒電極に向かって進展し，さらにチャンネルを加 熱する。これは負ストリーマに比べ，正ストリーマは低い
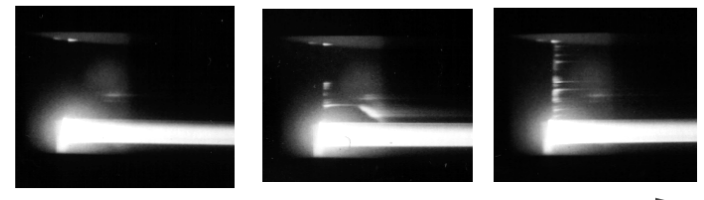

$\mathrm{Nob} / \mathrm{N}_{\mathrm{f}}$

0.15

0.4

0.85

図 7 プラズマチャンネルの発光写真

Fig. 7. Streak photograph of luminecing form the plasma channel.

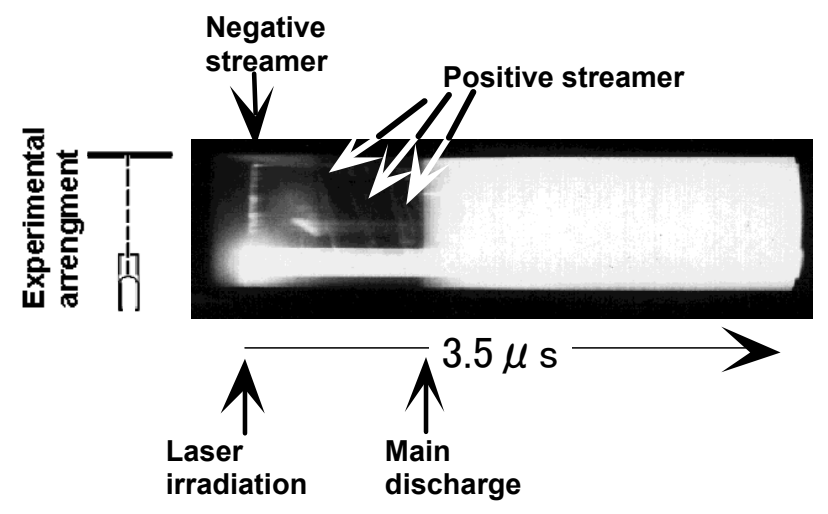

(a) ストリーク写真

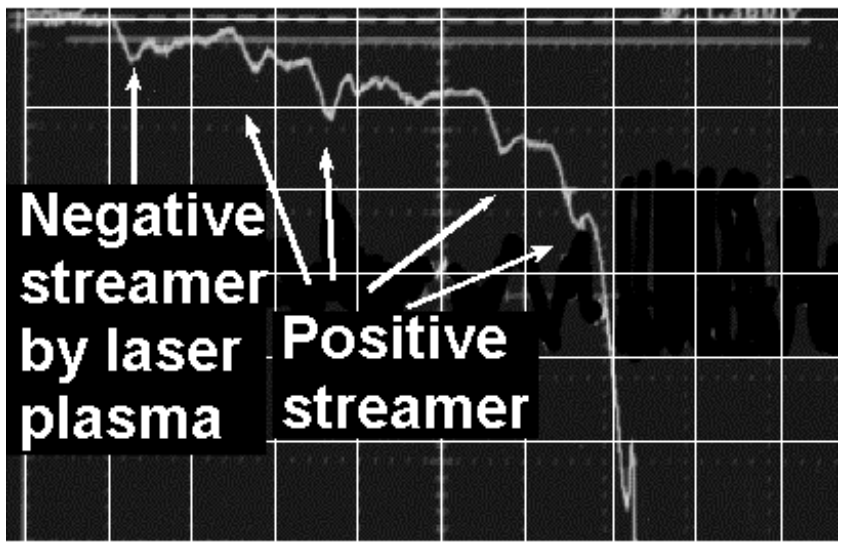

(b) 電流変化

1V/div, 200ns/div

図 8 放電誘導時のストリーク写真と電流変化

Fig. 8. Streak photograph of the discharge guiding and current changing at the discharge.

外部電界で進展することが可能であるためである ${ }^{(15)}$ 。また, 正ストリーマ進展速度は負ストリーマのそれに比べて遅 い。そして, 棒電極付近の電界が平板電極付近のそれに比 べて高いために, 正ストリーマの進展速度が棒電極側に進 むに連れて早くなる。

(b)図はレーザプラズマチャンネルにより負ストリーマが 進展し, その後, 正ストリーマ進展が生じ主放電に至ると きの電流変化である。ここで，レーザ繰り返し照射により 


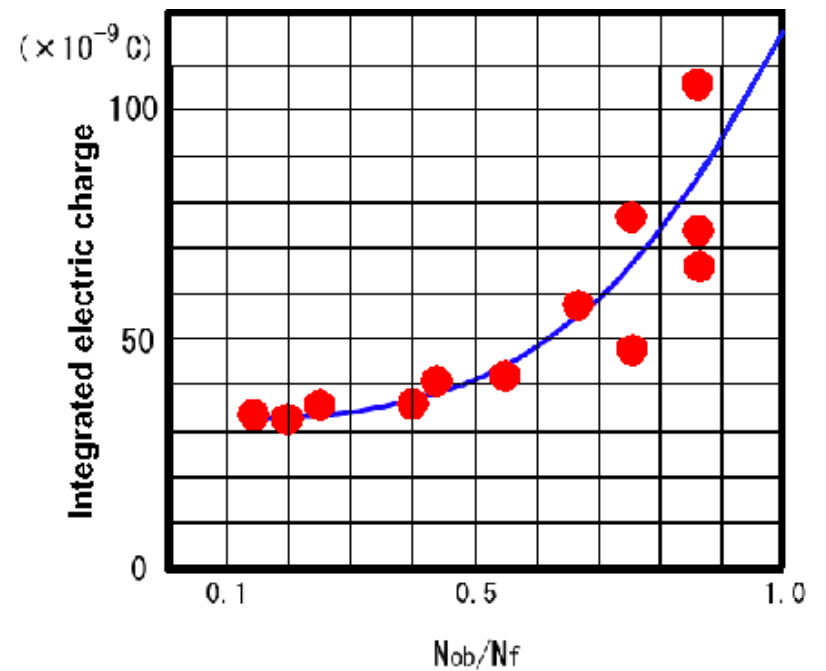

図 $9 \mathrm{~N}_{\mathrm{ob}} / \mathrm{N}_{\mathrm{f}}$ と電荷量の関係

Fig. 9. Mount of electric charge increase with increaseing $\mathrm{N}_{\mathrm{ob}} / \mathrm{N}_{\mathrm{f}}$.

プラズマチャンネルに流れた電荷量に着目する。プラズマ チャンネル密度条件がある闇值以上であれば，自己進展す る正ストリーマが発生し主放電に至るので，正ストリーマ が発生する閾值を求めることが必要なプラズマチャンネル の条件となる。レーザプラズマチャンネル中を流れる電荷 量を縦軸に, 主放電到達割合 $\mathrm{N}_{\mathrm{ob}} / \mathrm{N}_{\mathrm{f} 。}$ を横軸にプロットした 結果を図 9 に示す。図より, 主放電到達割合 $\mathrm{N}_{\mathrm{ob}} / \mathrm{N}_{\mathrm{f}}$ が〜 0.3 程度まではチャンネル中を流れる電荷量の変化は小さい。 その後，傾きが右上がりとなり，主放電到達割合が 1 に近 づくに従い次第に増加する。この曲線を 1 の所まで外掃す ると $115 \mathrm{nC}$ である。

強電離プラズマ部分は 1 気圧大気中のプラズマであるた めプラズマ温度は $1 \sim 2 \mathrm{eV}$ 程度で, 荷電粒子密度 $10^{17} \mathrm{~cm}^{-3(16)}$, 電気抵抗は $10^{-3} \Omega \mathrm{m}$ 程度である。この值は，ストリーマが 進展する密度 $10^{13} \sim 10^{15} \mathrm{~cm}^{-3(17)(18)}$ に比べて高く, 強電離プ ラズマにおける抵抗值は弱電離プラズマのそれより低い。

また，繰り返し照射によるプラズマ密度変化も小さいと考 えられる。このため, 強電離プラズマと弱電離プラズマ直 列に繋がった状態での全プラズマチャンネル抵抗值は弱電 離プラズマの抵抗值で決定される。

上記の議論から，150 kV の印加電圧は弱電離プラズマチ ヤンネルに印加されているとする。弱電離プラズマに流れ た電荷量を $115 \mathrm{nC}$, 電流が流れている時間を $100 \mathrm{~ns}$ すると, 弱電離プラズマチャンネル抵抗值は $150 \mathrm{kV} /(115 \mathrm{nC} / 100$ $\mathrm{ns})=130 \mathrm{k} \Omega$ である。プラズマチャンネルの断面積を感熱紙 についたパターンで評価し, 弱電離プラズマ抵抗率を求め ると約 $3.5 \Omega \mathrm{m}$ である。このことより，ストリーマの直径 より太く, かつ, 抵抗率 $3.5 \Omega \mathrm{m}$ 以下のプラズマを大気中 に生成することにより自己進展するストリーマを生成させ ることが出来る。これがストリーマを発生させるための必 要条件である。自己進展ストリーマがチャンネルを加熱し

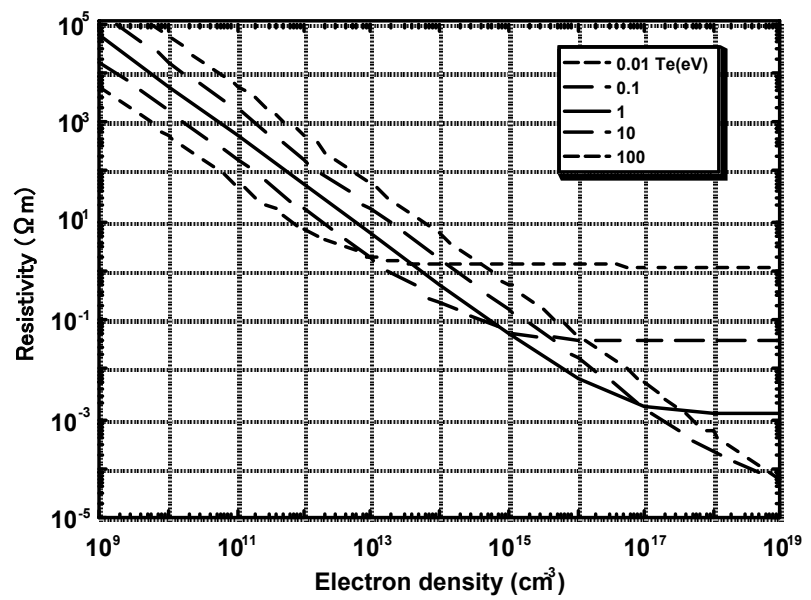

図 10 電子密度，温度に対する抵抗率

Fig. 10. Electric resistibity depends on electron density and temprature.

主放電に至る過程は, 初期に自己進展ストリーマが進展で きる程度のプラズマチャンネル抵抗值以下にすることによ り達成する。このため, 放電誘導するために能動的に行わ なければならない事柄は初期弱電離プラズマ抵抗值を 3.5 $\Omega \mathrm{m}$ 以下とすることが条件である。

一般にプラズマの抵抗率 $\eta$ は

$$
\eta=\frac{m_{e}\left(v_{e n}+v_{e i}\right)}{e^{2} \cdot n_{e}}
$$

で示される。 $\mathrm{m}_{\mathrm{e}}, v_{\mathrm{ne}}, v_{\mathrm{ei}}, \mathrm{e}, \mathrm{n}_{\mathrm{e}}$ はそれぞれ, 電子の質量, 電子と中性粒子との衝突周波数, 電子と荷電粒子との衝突 周波数, 電子電荷, 電子密度である。ここで, 中性粒子温 度を $400^{\circ} \mathrm{K}^{(19)}$, 1 気圧とした場合の電子密度, 温度に対す るプラズマの抵抗率変化を図 10 に示す ${ }^{(20)}$ 。大気中を進展す るストリーマの電子温度を約 $1-10 \mathrm{eV}{ }^{(21)}{ }^{(22)}$, 抵抗率を 3.5 $\Omega \mathrm{m}$ とすると, プラズマチャンネル内の電子密度は 1.5-6 $\times 10^{13} \mathrm{~cm}^{-3}$ である。したがって，ストリーマをガイドするた めには, $1.5 \times 10^{13} \mathrm{~cm}^{-3}$ 以上のプラズマ密度のチャンネルを能 動的に生成すれば，放電チャンネルは自己加熱するために 必要なチャンネル抵抗值以下となり, 自己放電誘導が生じ る。

大気中を進展するストリーマ内部のプラズマ密度は, $10^{13}$ $-10^{15} \mathrm{~cm}^{-3}$ であり, 今回の結果と比較すると同程度から 2 桁 低い值である。

\section{4. 結論}

本稿は，強電離・弱電離プラズマを用いた場合の放電誘 導過程の条件を導出した。レーザの照射を繰り返すと，チ ヤンネルに沿って負ストリーマが進展してチャンネルを加 熱する。これによりチャンネルに流れる電荷量が増加し, チャンネルの抵抗を減少させ, 最後に自己進展する正スト 
リーマが発生して主放電に至る。実験結果より自己進展す る正ストリーマを発生させるためにはチャンネルに $115 \mathrm{nC}$ 以上の電荷を流す必要がある。この条件では, チャンネル の抵抗率 $3.5 \Omega \mathrm{m}$, 電子密度 $1.5 \sim 6 \times 10^{13} \mathrm{~cm}^{-3}$ である。した がって，ストリーマをガイドするためには，上記以上の弱 電離プラズマ密度を生成する必要がある。

この研究を遂行するに当たり, 大阪大学卒業生の緒方淳 寿氏に感謝する。

(平成 10 年 10 月 7 日受付, 平成 15 年 7 月 4 日再受付)

\section{文献}

(1) L. M. Ball : "The Laser Lightning Rod System : Thunderstorm Domestication", Appl. Opt., Vol.13, No.10, pp.2292-2296 (1974)

(2) C. W. Schubert, J. Capt, and J. Lippert : "Investigation into triggering lightning with a pulsed laser", IEEE Int. Pulsed Power Conf., pp.132-135, USA (1979)

(3) T. Shindo and T. Suzuki : "Laser-induced gas breakdown and its application for lightning protection", Central Research Institute of Electric Power Industry, Electric Engineering Laboratory, Rep., No.182010 (1982) (in Japanese)

新藤孝敏・鈴木俊男 :「レーザによる気体の絶縁破壞と誘雷」, 電中 研調查報告, T182010 (1982)

(4) E. Fujiwara, Y. Izawa, Z. Kawasaki, K. Matsu-ura, and C. Yamanaka : "Laser triggered lightning", Rev. Laser Engineering, Vol.19, No.6, pp.528-537 (1991) (in Japanese)

藤原閲夫・伊澤靖和・河崎善一郎・松浦虔士・山中千代衛 : 「レーザ 一誘雷」, レーザー研究, 19, No.6, pp.528-537 (1991)

(5) Y. Shimada, S. Uchida, H. Yasuda, S. Motokoshi, C. Yamanaka, Z-I. Kawasaki, T. Yamanaka, Y. Ishikubo, and M. Adachi : "Laser triggered lightning", Proc. SPIE, Vol.3423, p.258 (1997)

(6) T. Yamanaka, S. Uchida, Y. Shimada, H. Yasuda, S. Motokoshi, K. Tsubakimoto, Z. Kawasaki, Y. Ichikubo, M. Adachi, and C. Yamanaka : "First observation of laser triggered lightning", Proc. of SPIE - Conference on High Power Laser Ablation-, Vol.3343, p.281 (1998)

(7) Y. Shimada, A. Ogata, S. Uchida, C. Yamanaka, H. Ishida, and K. Kawabata : "Laser plasma guiding discharge for laser-triggered lightning", Proc. of ICPIG 2001 International Conference, Vol.1, p.283 (2001)

(8) M. Jinno, M. Kubo, and R. Itatani : "Triggering Dischaarge and Guiding Discharge Path by Weak ionized channel with Different Wavelength Laser Beams", T. IEE Japan, Vol.115-A, No.7, pp.595-604 (1995-7) (in Japanese)

神野雅文・久保 定・板谷良平: 「非発光電離路を用いた異波長レー ザ併用による放電の誘発と誘導」, 電学論 A, 115, 7, pp.595-604, (1995-7)

(9) M. Uchiumi, H. Hayashi, K. Ueda, K. Muraoka, F. Kinoshita, M. Akazaki, T. Tanaka, and C. Honda : "Optimization of usage of UV and IR Laser in inducing an impulse discharge", T. IEE Japan, Vol.119-A, No.6, pp.828-834 (1999-6) (in Japanese)

内海通弘 - 林 宏充 - 植田清隆 - 村岡克紀 - 木下文宏 - 赤崎正則 田中祀捷・本田親久: 「紫外・赤外レーザ併用による放電誘導特性の 向上」, 電学論 A, 119, 6, pp.828-834 (1999-6)

(10) J. Sasaki, S. Kubodera, R. Ozaki, and T. Uchiyama : "Characteristics of interelectrode flashover in air with the existence of a weakly ionized plasma channel induced by a KrF laser (248nm)", J. Appl. Phys., Vol.60, p.3845 (1986)

(11) K. Nakamura, T. Suzuki, C. Yamabe, and K. Horii : "Fundamental Research for Lightning Trigger Experiment by Using UV Lasers", T. IEE Japan, Vol.113-A, No 11, p.1265 (1993-11) (in Japanese) 中村圭二・鈴木孝光・山部長兵衛・堀井憲爾：「紫外レーザを用い たレーザ誘雷の基礎的検討」, 電学論 B, 113, 11, p.1265 (1993-11)

(12) M. Yamaura, N. Hayashi, S. Ihara, S. Satoh, and C. Yamabe : "Investigation of Weakly ionized Plasma Channel by Accumulation Effect of Charged Particles Using High Repetition Rate KrF Laser", T. IEE Japan, Vol. 121-A, No. 9, p. 828 (2002) (in Japanese)
山浦道照・林 信哉・猪原 啓・佐藤三郎・山部長兵衛：「高繰り 返し $\mathrm{KrF}$ エキシマレーザを用いた荷電粒子蓄積効果による弱電離プ ラズマチャネルの検討」, 電学論 A, 121, 9, p.828 (2001-9)

(13) Y. Shimada, S. Uchida, C. Yamanaka, A. Ogara, T. Yamanaka, Z-I. Kawasaki, E. Fujiwara, Y. Ishikubo, and K. Kawabata : "Experiments of discharge guiding using strongly and weakly ionized plasma channels for laser-triggered lightning", Proc. of SPIE - High-Power Lasers in Energy Engineering -, Vol.3886, p.663 (1999)

(14) 藤田博之:「直流パルス性正針コロナ場の簡便電界計算法」, 電学論 A, Vol.100, No.6, p.323 (1980-6)

(15) C. T. Phelps : "field-Enhanced Propagation of Corona Streamers", J. Geophysical Res., Vol.76, №.24, p.5799 (1971)

(16) 本田親久 - 古賀誠一 ・中澤雅明 - 内野喜一郎 - 村岡克紀 - 宅間 董 木下文宏・片平 治・赤崎正則：「レーザによる大気中の放電誘導 特性 ( 7 ) 」, 電気学会放電高電圧合同研資, ED-92-75, HV-92-13, p.39 (1992)

(17) I. Gallimberti : "A computer model for streamer propagation", J. Phys. D:Appl. Phys., Vol.5, p.2179 (1972)

(18) R. T. Water : "breakdown in nonuniform fields", IEE Proc., Vol.128-A, p.319(1981)

(19) D. M. Phillips : "Deternination of gas temperature from unresolved bands in the spectrum from a nitrogen discharge", J. Phys. D: Appl. Phys., Vol.9, p.507 (1976)

(20) 例えば, F. F. Chen : プラズマ物理学, 丸善 (1976)

(21) A. Gibert, J. Dupuy, M. Bayle, and P. Bayle : "Schieren study of the transition to spark of a discharge in air and $\mathrm{SF}_{6}$ ", J. Phys. D: Appl. Phys., Vol.16, p.1493 (1983)

(22) G. Hartmann and I. Gallimberti : "The influence of metastable molecules on the streamer progression", J. Phys. D: Appl. Phys., Vol.8, p.670 (1975)

島田義 則 (正員) 1965 年 12 月 8 日生まれ。1990 年 3 月

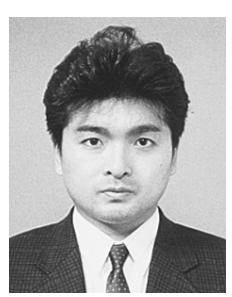

会各会員。 大阪大学大学院工学研究科電磁エネルギー工 学専攻博士前期課程終了。同年ヤマ八発動機 （株）入社。1992 年 6 月（財）レーザー技術総 合研究所入所。レーザ誘導放電, レーザープラ ズマに関する研究に従事。1998 年レーザー学会 進歩賞受賞。放電学会, 応用物理学会, プラズ マ核融合学会, レーザー学会, 日本大気電気学

内田成明（正員） 1959 年 4 月 10 日生まれ。1992 年 7 月

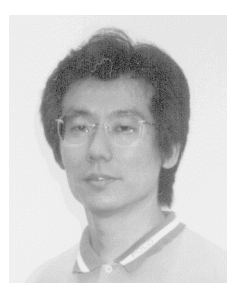
米国ロチェスター大学院工学研究科博士課程 終了。同年 10 月（財）レーザー技術総合研究 所入所。工学博士。レーザ誘導放電, レーザー プラズマ, レーザー推進ロケットに関する研究 に従事。1998 年レーザー学会進歩賞受賞。アメ リカ物理学会, レーザー学会, 日本大気電気学 会各会員。

河 崎 善一郎 （正員） 1949 年 1 月 17 日生まれ。1978 年 3 月

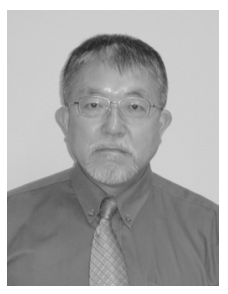
大阪大学大学院博士課程終了。1979 年 4 月名古 屋大学空電研究所入所。1 989 年 7 月大阪大学工 学部講師。1991 年同助教授。2000 年大阪大学大 学院教授。工学博士。電波理工学, 大気電気学, 環境電磁工学, 電気工学に関する研究に従事。 1998 年レーザー学会進歩賞受賞。1992 年日本大 気電気学会賞受賞。気象学会, 日本大気電気学 会, AGU, IEEE 各会員。 


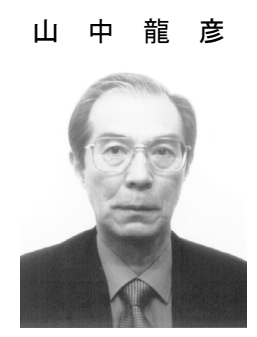

（正員） 1938 年月日生まれ。1963 年 3 月大阪 大学大学院工学研究科博士課程単位取得退学。 日本学術振興会奨励研究員を経て大阪大学工 学部電気工学科助手, 同レーザー工学研究施設 助教授, 名古屋大学プラズマ研究所助教授, 大 阪大学レーザー核融合研究センター助教授を 経て 1980 年大阪大学工学部電磁エネルギー工 学専攻教授, 1985 年大阪大学レーザー核融合 研究センター教授。1 999 年同センター長。2002 年福井工業大学教 授。工学博士。レーザによる核融合及び高出力レーザ応用, 光学素 子, 高出力レーザの研究に従事。1998 年レーザー学会進歩賞受賞。 電気学会学術振興賞, レーザー学会学術振興賞受賞。レーザー学会, 日本物理学会, 応用物理学会, プラズマ・核融合学会, 日本原子力 学会, 米国物理学会各会員。

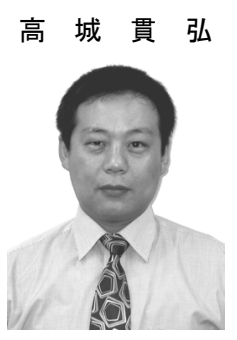

（正員） 1969 年 3 月 2 日生まれ。1994 年 3 月 大阪府立大学大学院工学研究科電気工学専攻博 士前期課程修了。同年 4 月関西電力株式会社入 社。2001 年総合技術研究所電力技術研究所流通 設備研究室 (送電) , 2003 年研究開発室電力技 術研究所電力基盤技術研究室（流通）勤務。主 に送電線の保守, 設計等に携わり, 2001 年から 送電線関係の研究・開発に従事。
古 岡 芳 弘 (正員) 1955 年 12 月 17 日生まれ。1978 年 3

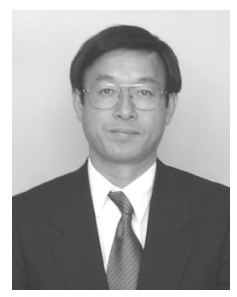
月福井大学工学部電気工学科卒業。同年 4 月関 西電力株式会社入社。2001 年総合技術研究所電 力技術研究所流通設備研究室 (送電) 主幹, 2003 年研究開発室勤務。

山 中 千代衛 (名誉員) 1923 年 12 月 14 日生まれ。1948 年

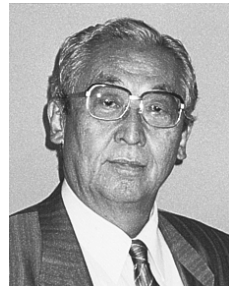
大阪大学工学部電気工学科卒業。1953 年大阪大 学大学院特別研究生修了, MIT 大学留学。工学 博士。大阪大学工学部助手, 講師, 助教授を経 て 1963 年大阪大学教授, レーザー工学研究施 設長, 同大学レーザー核融合研究センター長を 歴任。1987 年同大学名誉教授。（財）レーザー 技術総合研究所長で現在に及ぶ。1990 年姫路工 業大学学長, 1995 年同大学名誉教授。電気学会会長, レーザー学会 会長歴任。プラズマ物理, レーザ工学, 核融合工学の研究に従事。 電子情報通信学会, 照明学会, 原子力学会, プラズマ・核融合学会, 応用物理学会, 高温学会各会員。電気学会功績賞, 進歩賞, 論文賞。 レーザー学会功績賞, 進歩賞。IEEE ライフフェロー, APS フェロ 一, 米国核融合協会研究推進賞, エドワード・テラー賞。紫綬襄章 受章。勲二等瑞宝章受章。 